\title{
PERAN MODEL PEMBELAJARAN KONFLIK INTELEKTUAL TERHADAP KECERDASAN INTERPERSONAL MAHASISWA
}

\author{
Sri Wahyuni \\ Universitas Islam Negeri Sumatera Utara Medan \\ E-mail: sriwahyuni@uinsu.ac.id \\ Rina Devianty \\ Universitas Islam Negeri Sumatera Utara Medan \\ E-mail: rinadevianty@uinsu.ac.id
}

Article received: 7 February 2019, Review process: 15 February 2019

Article published: 30 March 2019

\begin{abstract}
This paper presents the application of the intellectual conflict learning model in the context of the emotional development of children in the age of $R A$ and their role in the interpersonal intelligence of students. This type of research is mixed methods. The tools used in this study are questionnaires, observational sheets and document studies. Analysis of the data used in this study: qualitative data analysis by Miles and Huberman and analysis of quantitative data using simple regression tests. The results showed that: (1) the application of the intellectual conflict learning model had an impact on the cognitive aspects of the emotional development of children, affective and psychomotor in the emotional development of RA children; and (2) the intellectual conflict learning model provides a positive role for the interpersonal intelligence of the students.
\end{abstract}

Keywords: interpersonal intelligence, emotional development of children, intellectual conflicts

\section{Abstrak}

Tulisan ini menyajikan tentang penerapan model pembelajaran konflik intelektual pada mata kuliah pengembangan emosional anak usia RA, dan perannya terhadap kecerdasan interpersonal mahasiswa. Jenis penelitian ini merupakan penelitian metode campuran (mixed methods). Instrumen yang digunakan pada penelitian ini yaitu angket, lembar observasi, dan studi dokumen. Analisis data yang digunakan pada penelitian ini, yaitu: analisis data kualitatif Miles dan Huberman, dan analisis data kuantitatif menggunakan uji regresi sederhana. Hasil penelitian menunjukkan bahwa: (1) Penerapan model pembelajaran konflik intelektual berdampak pada aspek kognitif mengenai permasalahan pengembangan emosional anak, afektif dan psikomotorik pada mata kuliah Pengembangan Emosional anak usia RA; dan (2) model pembelajaran konflik intelektual memberikan peran positif terhadap kecerdasan interpersonal mahasiswa.

Kata kunci: kecerdasan interpersonal, perkembangan emosi anak, konflik intelektual 


\section{PENDAHULUAN}

Proses pembelajaran memerlukan adanya model atau strategi pembelajaran agar diperoleh hasil yang memuaskan. Namun, dalam proses tersebut ditemukan adanya kendala yang mempengaruhi hasil belajar, sehingga dalam proses belajar ini dibutuhkan model pembelajaran yang tepat untuk menghindari terjadinya hasil belajar yang tidak memuaskan tersebut. Salah satu model yang dapat digunakan adalah pembahasan konflik. Pembahasan konflik merupakan salah satu cara yang dapat diterima untuk menarik perhatian orang lain. Kekuatan konflik dapat terlihat jelas dalam bidang seni, para pemain drama, pemain, dan penulis naskah untuk menciptakan konflik kapan pun yang diinginkan, mempertahankan perhatian penonton, menciptakan daya tarik dan, keterlibatan emosional.

Menciptakan suatu konflik merupakan suatu alat pembelajaran yang dapat diterima oleh guru atau pengajar. Namun, tidak semua pengajar memiliki kompetensi untuk mau mengubah pola pengajaran yang baru. Dosen lebih memilih cara yang umum dengan hanya memberikan kuliah dengan ceramah dan tugas seperti kebiasaan di lingkungan kampus. Cara pengajaran yang umum ini membuat siswa menjadi kurang aktif dalam belajar, malas untuk bertanya, kurang fokus dan membosankan. Kendala ini tidak berhenti sampai di sini, namun ada kendala lain, seperti kurangnya fasilitas pembelajaran, yaitu kurang tersedianya infokus, ruangan yang panas, serta koleksi buku yang masih terbatas. Selain kendala di atas, juga ada permasalahan lain, yakni mahasiswa tidak diberikan wadah untuk mengembangkan kecerdasan interpersonalnya melalui wadah pembelajaran dengan model konflik intelektual yang berupa adu debat. Hal ini merupakan kendala besar yang harus diatasi jika dosen menggunakan kekuatan konflik intelektual dalam mengajar. Oleh karena itu, dosen diharapkan lebih berani untuk mengubah praktik mengajar mereka dan memasukkan konflik sebagai pusat dalam seni mengajar.

Sementara dalam proses pembelajaran diharapkan mahasiswa memberikan respon terhadap hasil pembelajaran dengan bertanya dan mengungkapkan apa yang mereka terima mengenai materi ataupun kasus yang mungkin dihadapi oleh mahasiswa, di mana mahasiswa di tuntut utuk aktif selama prose pembelajaran berlangsug. Akan tetapi, tidak semua mahasiwa mampu memberikan respon yang diharapkan. Mahasiswa cenderung diam dan malas bertanya sehingga terkadang dosen harus bertanya lebih dahulu kepada mahasiswa secara satu per satu. 
Kenyataan di lapangan pada Prodi Pendidikan Anak Usia Dini FITK UIN SU Medan ditemukan bahwa tidak semua mahasiswa mampu mengikuti materi yang diberikan. Hal ini disebabkan kurangnya pemahaman dan kemampuan mahasiswa dalam menerima dan mengatasi permasalahan, kurangnya kemampuan mahasiswa dalam mengomunikasikan, kurangnya sikap kerja sama untuk mendiskusikan kasus yang terjadi, hanya $25 \%$ mahasiswa yang rutin bertanya dan aktif dalam diskusi kelas, mahasiswa masih membentuk kelompokkelompok sendiri dan kurang mau berbaur dengan yang lain. Selain itu, mahasiswa tidak terbiasa menerima materi dengan membahas kasus aktual dan berkaitan dengan materi pembelajaran. Dari proses perkuliahan ditemukan bahwa belum ada yang menerapkan model pembelajaran konflik intelektual, khususnya pada mata kuliah pengembangan emosional anak usia RA. Temuan lain dari observasi yakni rendahnya kecerdasan interpersonal mahasiswa, bahkan mahasiswa tidak memahami konsep kecerdasan interpersonal.

Dengan kondisi seperti ini, dosen melakukan perubahan dengan menggunakan model pembelajaran konflik intelektual dengan menyajikan kasus-kasus yang sejalan dengan materi pembelajaran. Model dan pendekatan pembelajaran dengan konflik intelektual diharapkan akan membantu pemahaman dan berpikir kreatif mahasiswa dengan cara mempengaruhi seseorang dalam memandang permasalahan dari sudut pandang yang berbeda dan memformulasikan kembali masalah dengan cara yang membantu munculnya orientasiorientasi baru terhadap solusi. Kontroversi memberikan pemahaman yang lebih akurat dan lengkap terhadap perspektif yang berlawanan. Kontroversi juga meningkatkan munculnya ide-ide, perasaan stimulasi dan kenikmatan serta keaslian ekspresi dalam masalah yang kreatif.

Penelitian ini didukung oleh penelitian terdahulu yakni: Nurhayani (2015:345) dalam penelitiannya mengemukakan bahwa melalui model dan pendekatan pembelajaran konflik intelektual akan dapat mengasah dan meningkatkan kecerdasan interpersonal mahasiswa sehingga kelak bukan hanya menjadi sarjana yang cerdas secara intelektual mengatasi konflik-konflik kehidupan namun juga memiliki kemampuan menghargai perbedaan dan berfikir secara beragam. Hasil penelitian tersebut mendukung penelitian ini karena terbukti bahwa penerapan konflik dalam pembelajaran dapat mempengaruhi kecerdasan, baik itu kecerdasan emosi maupun interpersonal. 
Pembelajaran konflik intelektual dikembangkan dari teori konstruktivisme Piaget. Konstruktivisme Piaget menekankan proses rekonstruksi kognitif melalui porses asimilasi dan akomodasi sehingga ketika terjadi konflik atau ketidakseimbangan struktur kognitif pada informasi lama dengan informasi yang akan dibahas maka secara sadar mahasiswa akan berupaya menyeimbangkan atau memecahkan konflik tersebut. Proses konflik intelektual menurut Lee dan Kwon (dalam Prasetyo, 2009) meliputi tiga tahapan, yakni: (a) pendahuluan (preliminary), dilakukan dengan penyajian konflik kognitif; (b) konflik (conflict), penciptaan konflik dengan bantuan kegiatan demonstrasi atau eksperimen yang melibatkan proses asimilasi dan akomodasi; dan (c) penyelesaian (resolution), kegiatan diskusi dan menyimpulkan hasil diskusi. Dengan kata lain, pembelajaran konflik intelektual secara tidak langsung melatih kecerdasan interpersonal mahasiswa karena dalam memecahkan konflik dibutuhkan kesadaran, empati, kepemimpinan, kepekaan dan sosialisasi yang tinggi. Anderson (dalam Safaria, 2015:10) mengemukakan bahwa kecerdasan interpersonal mempunyai tiga dimensi utama, yakni: (1) social sensitivity, yaitu sikap empati dan sikap prososial; (2) social insight, yaitu kesadaran diri, etika sosial, dan pemecahan masalah; dan (3) social communication, yaitu komunikasi dan mendengarkan efektif. Oviyanti (2017:75) mengemukakan bahwa kecerdasan interpersonal merujuk pada kemampuan seseorang untuk menjalin hubungan sosial yang baik dengan indikatornya antara lain sikap empati, pro sosia, kesadaran diri, kemampuan pemecahan masalah efektif, serta kemampuan berkomunikasi efektif. Kecerdasan ini amat dibutuhkan guru maupun calon guru dalam memenuhi kebutuhan akan kompetensi kepribadian dan kompetensi sosialnya sebagai pendidik.

Dari uraian di atas, maka pemberian kasus atau pembahasan isu-isu aktual dalam pembelajaran sangatlah penting dan menjadikan pembelajaran lebih bermakna. Bahkan penerapan model pembelajaran konflik intelektual dianggap akan berkontribusi untuk mahasiswa lebih aktif, berpengetahuan dan berpengalaman. Oleh karena itu, peneliti tertarik melakukan penelitian dengan judul "Peran Model Pembelajaran Konflik Intelektual terhadap Kecerdasan Interpersonal Mahasiswa”.

Berdasarkan uraian di atas, maka dirumuskan beberapa masalah yaitu: (1) Bagaimana penerapan model pembelajaran konflik intelektual pada mata kuliah pengembangan emosional anak usia RA? dan (2) Apakah ada peran positif model pembelajaran konflik intelektual terhadap kecerdasan interpersonal mahasiswa? 


\section{METODOLOGI}

Jenis penelitian ini merupakan penelitian metode campuran (mixed methods). Sugiyono (2013) mengemukakan bahwa desain penelitian metode campuran (mixed methods research design) adalah suatu prosedur untuk mengumpulkan, menganalisis, dan mencampur metode kuantitatif dan kualitatif dalam suatu penelitian atau serangkaian penelitian untuk memahami permasalahan penelitian. Begitu juga prosedur yang diterapkan pada penelitian ini, yakni menerapkan metode kualitatif dan metode kuantitatif secara berbarengan dalam satu penelitian. Metode kualitatif digunakan untuk menganalisis penerapan model pembelajaran konflik intelektual pada mata kuliah pengembangan emosional anak usia RA. Sedangkan metode kuantitatif digunakan untuk menganalisis peran model pembelajaran konflik intelektual terhadap kecerdasan interpersonal mahasiswa, dan faktor lain yang berperan.

Menurut Lincoln dan Guba (1985) bahwa subjek penelitian adalah peristiwa, manusia dan situasi yang diobservasi. Subjek pada penelitian ini ditentukan menggunakan teknik sampling purposive. Sugiyono (2013) menambahkan bahwa Sampling Purposive adalah teknik penentuan sampel dengan pertimbangan tertentu. Berdasarkan pertimbangan tertentu, maka ditentukan subjek pada penelitian ini adalah 30 orang mahasiswa PIAUD semester III. Adapun objek yang diteliti, yaitu: peran model pembelajaran konflik intelektual terhadap kecerdasan interpersonal mahasiswa.

Teknik pengumpulan data menurut Creswell (2015) merupakan langkah yang paling strategis dalam penelitian, karena tujuan utama dari penelitian adalah mendapatkan data. Data pada penelitian mixed methods berupa data kualitatif dan data kuantitatif. Oleh karena itu, pada penelitian ini menggunakan instrumen lembar observasi dan studi dokumen lembar kerja kelompok mahasiswa untuk memperoleh data kualitatif, dan menggunakan instrumen angket untuk memperoleh data kuantitatif.

Analisis data yang digunakan pada penelitian ini juga terbagi menjadi dua, yaitu: analisis data kualitatif dan analisis data kuantitatif. Analisis data kualitatif mengikuti prosedur Miles dan Huberman (1994), yakni dilakukan secara interaktif dan berlangsung secara terusmenerus sampai tuntas dan datanya sudah jenuh. Aktivitas dalam analisis data ini meliputi data reduction, data display, dan conclusions: drawing/verification. Analisis data kuantitatif menggunakan rumus uji regresi sederhana. Usman (2009:216) mengemukakan bahwa analisis regresi berguna untuk mendapatkan hubungan fungsional antara dua variabel atau lebih. Pada 
penelitian ini hanya ada satu variabel bebas (model pembelajaran konflik intelektual) dan satu variabel terikat (kecerdasan interpersonal) maka uji yang digunakan adalah uji regresi sederhana atau regresi tunggal.

\section{HASIL DAN PEMBAHASAN}

Penerapan model pembelajaran konflik intelektual dilaksanakan pada mata kuliah pengembangan emosional anak usia RA di PIAUD Semester 3 Tahun Akademik 2018/2019. Penelitian ini dilakukan pada pertemuan perkuliahan ketiga sampai dengan kelima yang membahas tentang permasalahan pengembangan emosional anak dengan beberapa kasus, yakni: Temper Tantrum (pertemuan ketiga), Enuresis (pertemuan keempat), dan Aggresivitas (pertemuan kelima). Kasus-kasus tersebut disajikan sebagai bahan pembelajaran konflik intelektual. Sebelum kegiatan pembelajaran konflik intelektual dimulai maka mahasiswa diminta duduk berdasarkan kelompoknya.

Pertemuan perkuliahan ketiga dengan menerapkan model pembelajaran konflik intelektual dimulai seperti biasanya, yaitu: salam dan berdoa, namun untuk pengisian absensi dilakukan sebelum mahasiswa memasuki ruangan. Kegiatan appersepsi dilakukan dengan bertanya jawab mengenai konsep pengembangan emosional, konsep kecerdasan Interpersonal, dan kaitan kedua konsep tersebut dalam pembelajarannya di PAUD/RA. Kemudian mahasiswa mengisi angket kecerdasan Interpersonal untuk digunakan sebagai data pretes. Kegiatan inti pun dimulai ketika dosen memberikan lembar kerja kelompok dan naskah yang memuat kasus Temper Tantrum. Mahasiswa diminta berdiskusi dengan teman satu kelompoknya untuk mengerjakan lembar kerja kelompok mengenai konflik tersebut. Data lembar kerja kelompok dijadikan sebagai studi dokumen.

Dari hasil studi dokumen ketiga lembar kerja kelompok diperoleh bahwa keseluruhan mahasiswa memahami kasus Temper Tantrum dan cara penangannya secara lengkap. Namun ketika penyampaian hasil diskusi dan proses diskusi ditemukan bahwa terjadi beberapa kendala atau kurang lancar. Hal tersebut sejalan dengan hasil observasi yang menunjukkan bahwa mahasiswa mampu menjelaskan secara lengkap namun kurang lancar mengenai konsep Temper Tantrum, permasalahannya, serta penanganannya. Dari hasil observasi secara terperinci diperoleh bahwa: (1) mahasiswa berkategori lengkap dan lancar pada indikator kemampuan menyebutkan pengertian dan karakteristik Temper Tantrum, kemauan berbagi dan mendengarkan orang lain, serta kemampuan berbicara secara jelas dan santun; dan (2) 
mahasiswa berkategori lengkap namun kurang lancar pada indikator kemampuan menjelaskan penyebab, menyelesaikan masalah dan menemukan solusi pada kasus Temper Tantrum, kemampuan mengendalikan diri dan memotivasi orang lain, serta kemauan mengarahkan dan mengatur orang lain (memimpin atau bekerjasama dengan kelompoknya).

Hasil penelitian mengenai konflik Temper Tantrum senada dengan beberapa hasil penelitian terdahulu, diantaranya yakni: Hasil penelitian Sulistyorini (2016:234) menunjukkan bahwa Permainan kooperatif dapat menurunkan reaksi temper tantrum pada anak usia prasekolah. Terdapat beberapa faktor yang menyebabkan terjadinya temper tantrum, diantaranya adalah terhalangnya keinginan anak mendapatkan sesuatu, ketidakmampuan anak mengungkapkan diri, pengaruh pola asuh orangtua, anak sedang stress dan merasa tidak aman, mencari perhatian, dan temper tantrum juga bisa muncul karena anak ingin menunjukkan kemandirian. Penelitian Kristiyanto (2013:9) membuktikan bahwa keinginan subyek untuk melakukan permainan puzzle meningkat terus menerus di setiap pengamatan, dengan adanya motivasi dan reward yang diberikan sehingga temper tantrum yang dialami anak juga berkurang, anak menjadi lebih tenang dan bisa fokus terhadap kegiatan yang dilakukan. Hasil penelitian Wulansari (2015) menunjukkan bahwa upaya guru untuk mengatasi perilaku tantrum, yaitu: memberikan pujian, menasehati dengan cerita, menegur, memberikan reward, mengajarkan tanggungjawab, mengalihkan perhatian anak, dan meminta teman lain untuk tidak mengganggu. Hambatan yang dihadapi, yaitu: guru merasa terkendala (bingung) dalam mengatasi perilaku tantrum.

Dari beberapa hasil penelitian tersebut maka diperoleh bahwa sangat penting untuk memahami konsep Temper Tantrum dan terampil dalam menanganinya karena apabila salah penanganan maka dapat menyebabkan konflik emosional lainnya seperti agresif dan sebagainya. Oleh karena itu, faktor-faktor penyebab anak memiliki perilaku Temper Tantrum harus dianalisis agar dapat diberikan treatment atau penanganan masalah secara tepat. Diantara beberapa faktor yang dapat mengurangi atau meminimalisir perilaku Temper Tantrum pada anak, yaitu: pembelajaran atau pola pengajaran guru di sekolah seperti contoh pada beberapa hasil penelitian terdahulu yang menerapkan pembelajaran kooperatif, permainan puzzle, peran guru memberikan reward, memberikan perhatian lebih kepada anak.

Pertemuan perkuliahan keempat masih menerapkan model pembelajaran konflik intelektual dan dimulai dengan kegiatan seperti sebelumnya mengenai salam, berdoa, dan 
absensi. Namun appersepsi dilakukan dengan bertanya jawab mengenai kasus Temper Tantrum secara singkat dan mahasiswa tidak mengisi angket kecerdasan Interpersonal. Sama seperti pertemuan sebelumnya bahwa kegiatan inti dimulai ketika dosen memberikan lembar kerja kelompok dan naskah yang memuat kasus, namun kasusnya diganti dengan Enuresis. Mahasiswa diminta berdiskusi dengan teman satu kelompoknya untuk mengerjakan lembar kerja kelompok mengenai konflik tersebut. Data lembar kerja kelompok dijadikan sebagai studi dokumen.

Dari hasil studi dokumen ketiga lembar kerja kelompok diperoleh bahwa keseluruhan mahasiswa memahami kasus Enuresis dan cara penangannya secara lengkap. Namun ketika penyampaian hasil diskusi dan proses diskusi terlihat bahwa mahasiswa masih ragu-ragu dengan materi ataupun pemahamannya. Hal ini sejalan dengan hasil observasi yang menunjukkan bahwa mahasiswa mampu menjelaskan secara lengkap namun ragu-ragu mengenai konsep Enuresis, permasalahannya, serta penanganannya. Dari hasil observasi secara terperinci diperoleh bahwa: (1) mahasiswa berkategori lengkap namun kurang lancar pada indikator kemampuan menyebutkan pengertian dan karakteristik Enuresis, kemauan berbagi dan mendengarkan orang lain, dan kemampuan mengendalikan diri; (2) mahasiswa berkategori lengkap namun ragu-ragu pada indikator kemampuan menjelaskan penyebab, menyelesaikan masalah dan menemukan solusi pada kasus Enuresis, kemampuan berbicara secara santun dam memotivasi orang lain, serta kemauan mengarahkan dan mengatur orang lain (memimpin kelompok atau mengelola pembagian tugas di kelompoknya).

Hasil penelitian mengenai konflik Enuresis senada dengan beberapa hasil penelitian terdahulu, diantaranya yakni: Yusuf (2012) menyimpulkan bahwa anak usia 3-6 tahun di Desa Tarasu, Kecamatan Kajuara, Kabupaten Bone dari 55 anak masih ada sekitar 16 anak yang masih mengompol, akan tetapi sebagian besar sudah mampu mengontrol enuresis (mengompolnya). Dari hasil penelitian juga membuktikan bahwa ada hubungan yang signifikan antara toilet training dengan kontrol enuresis (mengompol) pada anak.

Penelitian Setiowati (2012:107) menyimpulkan bahwa dampak psikososial yang dialami oleh seorang remaja mixed enuresis atau nocturnal dan diurnal enuresis antara lain rasa malu dan merasa bersalah akibat kondisinya, subjek tidak memiliki banyak teman, menjadi korban bullying, merasa tidak disukai dan ditolak keberadaannya, jarang berinteraksi dengan teman, sensitif terhadap kritikan, dan pasif pada saat pelajaran berlangsung. Kondisi 
yang demikian menjadikan subjek kurang mendapat dukungan dari orang dewasa sekitarnya dan teman sebaya untuk proses pertumbuhan pribadi yang sehat. Oleh karena itu diperlukan adanya penanganan yang menyeluruh dengan mempertimbangkan aspek psikososial.

Maria, dkk (2013:464-465) membuktikan bahwa tidak terdapat hubungan antara enuresis dengan kejadian infeksi saluran kemih pada anak usia 6-8 tahun di SD negeri Malalayang. Faktor lain yang berkontribusi sebagai penyebab enuresis adalah tidur yang sangat nyenyak, kapasitas fungsi kandung kemih yang sedikit dalam menampung air seni, genetika, faktor-faktor kematangan dan gangguan-gangguan perkembangan. Masalah enuresis pada anak maupun remaja dapat berdampak pada kondisi psikologisnya. Oleh karena itu, enuresis merupakan suatu hal yang perlu diperhatikan dan ditangani.

Dari beberapa hasil penelitian tersebut maka diperoleh bahwa memahami konsep Enuresis dan penanganannya merupakan hal yang sangat penting karena perilaku Enuresis yang berkepanjangan bukan hanya berdampak pada psikologis si anak tetapi juga fisiknya, khususnya mengenai kandung kemih. Oleh karena itu, menganalisis faktor penyebab dari perilaku Enuresis yang dialami si anak dan solusi yang tepat sangat dibutuhkan. Diantara beberapa cara penanganan yang tepat untuk anak usia dini adalah dengan toilet training, bekerjasama dengan tim kesehatan untuk mengecek adanya infeksi saluran kemih walaupun terdapat penelitian yang menyatakan tidak ada hubungannya, dan terapi lainnya yang bisa dilaksanakan di sekolah maupun di rumah.

Pertemuan perkuliahan kelima juga menerapkan model pembelajaran konflik intelektual dan dimulai dengan kegiatan seperti sebelumnya mengenai salam, berdoa, dan absensi. Namun appersepsi dilakukan dengan bertanya jawab mengenai kasus Agresif secara singkat dan mahasiswa mengisi angket kecerdasan Interpersonal pada akhir pertemuan ini. Kegiatan inti dimulai ketika dosen memberikan lembar kerja kelompok dan naskah yang memuat kasus, namun kasusnya diganti dengan Agresif. Mahasiswa diminta berdiskusi dengan teman satu kelompoknya untuk mengerjakan lembar kerja kelompok mengenai konflik tersebut. Data lembar kerja kelompok dijadikan sebagai studi dokumen.

Dari hasil studi dokumen ketiga lembar kerja kelompok diperoleh bahwa keseluruhan mahasiswa memahami kasus Agresif dan cara penangannya secara lengkap dan rata-rata mahasiswa sudah lancar karena yakin dengan pemahaman yang ia miliki tentang kasus Agresif. Hal ini sejalan dengan hasil observasi yang menunjukkan bahwa mahasiswa mampu 
menjelaskan secara lengkap dan lancar mengenai konsep Agresif, permasalahannya, serta penanganannya. Dari hasil observasi secara terperinci diperoleh bahwa: (1) mahasiswa berkategori lengkap namun kurang lancar hanya pada dua indikator yaitu kemauan mengarahkan dan mengatur orang lain; dan (2) mahasiswa berkategori lengkap dan lancar pada keseluruhan kognitif (kemampuan menyebutkan pengertian, karakteristik, penyebab, penyelesaian masalah dan penemuan solusi kasus Agresif), keseluruhan afektif (kemampuan mengendalikan diri dan berbicara santun, serta kemauan berbagi dan mendengarkan orang lain), dan psikomotorik pada kemampuan memotivasi orang lain.

Hasil penelitian mengenai konflik Agresif senada dengan beberapa hasil penelitian terdahulu, diantaranya yakni: Penelitian Suprihatin mengungkapkan bahwa bentuk-bentuk perilaku subjek meliputi agresi verbal (mengungkapkan bahwa bentuk-bentuk perilaku subjek meliputi agresi verbal (mengumpat, mengejek, menjulurkan lidah) serta agresi non-verbal (memukul, menendang, dan mendorong). Faktor-faktor penyebab perilaku agresif pada subjek adalah pembelajaran, penguatan, serta pengalaman langsung. Hasil penelitian Restu dan Restu, dkk menyimpulkan bahwa terdapat tiga anak yang berperilaku agresif, yang terdiri dari agresif fisik, verbal dan terhadap benda. Yoshi dan Yusri (2013:249) mengemukakan bahwa terdapat empat faktor yang menjadi penyebab terjadinya perilaku agresif dari ketiga anak tersebut, yaitu: frustasi, kekuasaan dan kepatuhan, provokasi, dan suhu udara. Disarankan kepada guru untuk menciptakan suasana menyenangkan di dalam kelas, menggunakan media yang menarik, dan bahasa yang baik sehingga anak lebih fokus dan tertarik dalam belajar, bersikap tenang, dan mengurangi terjadinya perilaku agresif ketika pembelajaran berlangsung.

Tentama (2012:169) membuktikan bahwa pelatihan menggunakan metode belajar sosial dari Albert Bandura dengan menggunakan prinsip modeling (transfer modeling) akan memberikan banyak kesempatan kepada keluarga dan masyarakat untuk belajar menjadi figure/ model yang dicontoh anak-anak sebagai upaya mendidik anak di dalam lingkungan inti dan sekitar sehingga perilaku agresif akan terminimalisir. Susantyo (2011:189) mengemukakan bahwa banyak kasus kekerasan yang terjadi merupakan manifestasi dari perilaku agresif, baik kekerasan verbal maupun non verbal. Beberapa pendekatan telah mencoba untuk memahami perilaku agresif ini, mulai dari pendekatan biologis, psikologis, situasional sampai dengan model socioecological. Pada kenyataannya, menjadi agresif bukan merupakan sesuatu yang tidak dapat dihindari, melainkan hanya merupakan strategi opsional 
belaka. Salah satu teknik yang dewasa ini tengah ramai diujicobakan adalah melalui latihan mengelola amarah (anger management).

Dari beberapa hasil penelitian di atas, maka diperoleh bahwa sangat penting untuk diterapkan pemahaman dan penanganan perilaku Agresif, baik di kalangan anak usia dini maupun di kalangan remaja. Perilaku agresif bukan hanya merugikan diri si anak yang mengalaminya tetapi juga merugikan orang di sekitarnya karena perilaku agresif cenderung menyakiti orang di sekitarnya dan merusak benda yang ada di dekatnya. Oleh karena itu, penanganan perilaku Agresif secara tepat dan cepat sangat dibutuhkan agar tidak hanya meminimalisir perilaku tersebut pada anak yang bersangkutan tetapi juga menghindari adanya dampak negatif yang lebih besar. Dari hasil penelitian di atas juga diperoleh beberapa cara penanganan perilaku Agresif yang dapat dilakukan oleh guru di sekolah, seperti: menciptakan suasana menyenangkan di dalam kelas, menggunakan media yang menarik, dan bahasa yang baik sehingga anak lebih fokus dan tertarik dalam belajar, bersikap tenang, dan mengurangi terjadinya perilaku agresif ketika pembelajaran berlangsung. Pelatihan menggunakan metode belajar sosial Albert Bandura dengan prinsip modeling (transfer modeling) juga memberikan banyak kesempatan kepada keluarga dan masyarakat untuk belajar menjadi figure/ model yang dicontoh anak-anak sebagai upaya mendidik anak tidak berperilaku Agresif. Beberapa contoh penanganan tersebut karena disesuaikan dengan faktor-faktor penyebab perilaku Agresif, yakni: pembelajaran, penguatan, serta pengalaman langsung.

Menurut Lore dan Schultz (dalam Krahe, 2001) bahwa Pencegahan perilaku agresif merupakan sebuah upaya besar untuk membina sebuah bangsa yang besar dan berjaya. Dengan memahami kompleksitas dan kerumitan perilaku agresif, akan dipahami pula bagaimana menyusun sebuah strategi yang komprehensif yang mampu menjawab permasalahan pada diri individu (pelaku), khususnya masalah perilakunya. Kendala strategis yang yang menghambat pengembangan strategi mencegah (atau bahkan menangani) perilaku agresif adalah sikap publik yang pada umumnya menganggap bahwa agresi atau kekerasan diri manusia dan tidak dapat dielakkan.

Dari uraian hasil studi dokumen dan observasi di atas, diperoleh bahwa penerapan model pembelajaran konflik intelektual menjadikan mahasiswa aktif dalam menemukan konsep permasalahan pengembangan emosional anak dan cara penanganan kasus-kasusnya yaitu Temper Tantrum, Enuresis dan Agresif. Sehingga pembelajaran bukan hanya berbentuk 
teoritis tetapi juga praktis atau bermakna bagi mahasiswa. Dengan menerapkan model pembelajaran konflik intelektual pada mata kuliah pengembangan emosional anak usia RA, mahasiswa bukan hanya memperoleh pengetahuan mengenai kasus-kasus yang berkaitan dengan pengembangan emosional anak, melainkan juga membina afektif dan melatih psikomotorik mahasiswa dalam kegiatan berkelompok untuk mencapai tujuan yang sama. Hal tersebut senada dengan hasil penelitian Setyowati dan Mosik (2011:89) membuktikan bahwa implementasi pendekatan konflik kognitif efektif digunakan dalam menumbuhkan kemampuan berpikir kritis, pemahaman konsep, dan hasil belajar kognitif.

Aspek kognitif, afektif dan psikomotorik yang ditemukan dalam penelitian ini merupakan aspek yang dicapai pada materi perkuliahan pengembangan emosional anak usia RA. Aspek kognitif, yaitu: kemampuan menyebutkan pengertian, karakteristik, penyebab, penyelesaian masalah dan penemuan solusi setiap kasus. Aspek afektif, yaitu: kemampuan mengendalikan diri, kemampuan berbicara santun, kemauan berbagi dengan orang lain, dan kemauan mendengarkan orang lain. Aspek psikomotorik, yaitu: kemampuan memotivasi orang lain, kemauan mengarahkan orang lain, dan kemauan mengatur orang lain.

\section{Peran Positif Model Pembelajaran Konflik Intelektual Terhadap Kecerdasan Interpersonal Mahasiswa}

Rerata skor postes menunjukkan bahwa mahasiswa yang menerapkan model pembelajaran konflik intelektual $(90,93)$ jauh lebih tinggi dari sebelum menerapkan model $(51,17)$. Perbandingan rerata skor tersebut mendukung hasil uji hipotesis yakni nilai sig. 0,001 lebih kecil 0,05 sehingga terbukti bahwa konflik intelektual berperan positif terhadap kecerdasan interpersonal. Bahkan diperoleh persamaan regresi sederhana yaitu: $\hat{Y}=42,513+$ 0,652 X, yang artinya model pembelajaran konflik intelektual memberikan peran positif terhadap kecerdasan interpersonal karena koefisien regresi bertanda positif, dan akan meningkatkan kecerdasan interpersonal sebesar 0,652 dari sebelumnya. Dengan demikian maka disimpulkan bahwa ada peran positif model pembelajaran konflik intelektual terhadap kecerdasan interpersonal mahasiswa prodi PIAUD FITK UIN Sumatera Utara Medan.

Hasil penelitian ini didukung beberapa penelitian terdahulu yang telah dipublikasi pada jurnal nasional maupun internasional, diantaranya yakni: Maulana (2010:98) menyimpulkan bahwa pembelajaran dengan pendekatan konflik kognitif merupakan salah satu pembelajaran yang dapat membantu siswa dalam membangun pengetahuannya sendiri. 
Hasil penelitian membuktikan bahwa pendekatan konflik kognitif dalam pembelajaran mempunyai pengaruh yang signifikan terhadap hasil belajar. Hasil penelitian Yu, et.al (2006:34-36) menemukan bahwa integrating and compromising conflict management styles can be most predicted by emotional intelligence. Hasil penelitian tersebut membuktikan bahwa sistem integrasi dan diskusi pada gaya manajemen konflik sangat dapat memprediksi kecerdasan emosional, yang artinya bahwa konflik dapat memberikan kontribusi atau peran terhadap kecerdasan. Gunkel, et.al (2016:568) menambahkan bahwa preferences for the conflict handling styles of compromising, obliging, and integrating towards emotional intelligence. Temuan penelitian membuktikan bahwa preferensi konflik pada gaya berkompromi, mewajibkan, dan berintegrasi dengan kecerdasan emosional.

Nurhayani (2015:345) dalam penelitiannya mengemukakan bahwa melalui model dan pendekatan pembelajaran konflik intelektual akan dapat mengasah dan meningkatkan kecerdasan interpersonal mahasiswa sehingga kelak bukan hanya menjadi sarjana yang cerdas secara intelektual mengatasi konflik-konflik kehidupan namun juga memiliki kemampuan menghargai perbedaan dan berfikir secara beragam. Uraian beberapa hasil penelitian terdahulu tersebut mendukung penelitian ini karena terbukti bahwa penerapan konflik dalam pembelajaran dapat mempengaruhi kecerdasan, baik itu kecerdasan emosi maupun interpersonal.

Pembelajaran konflik intelektual dikembangkan dari teori konstruktivisme Piaget. Konstruktivisme Piaget menekankan proses rekonstruksi kognitif melalui porses asimilasi dan akomodasi sehingga ketika terjadi konflik atau ketidakseimbangan struktur kognitif pada informasi lama dengan informasi yang akan dibahas maka secara sadar mahasiswa akan berupaya menyeimbangkan atau memecahkan konflik tersebut. Proses konflik intelektual menurut Lee dan Kwon (dalam Prasetyo, 2009) meliputi tiga tahapan, yakni: (a) pendahuluan (preliminary), dilakukan dengan penyajian konflik kognitif; (b) konflik (conflict), penciptaan konflik dengan bantuan kegiatan demonstrasi atau eksperimen yang melibatkan proses asimilasi dan akomodasi; dan (c) penyelesaian (resolution), kegiatan diskusi dan menyimpulkan hasil diskusi. Dengan kata lain, pembelajaran konflik intelektual secara tidak langsung melatih kecerdasan interpersonal mahasiswa karena dalam memecahkan konflik dibutuhkan kesadaran, empati, kepemimpinan, kepekaan dan sosialisasi yang tinggi. Anderson (dalam Safaria, 2015:10) mengemukakan bahwa kecerdasan interpersonal 
mempunyai tiga dimensi utama, yakni: (1) social sensitivity, yaitu sikap empati dan sikap prososial; (2) social insight, yaitu kesadaran diri, etika sosial, dan pemecahan masalah; dan (3) social communication, yaitu komunikasi dan mendengarkan efektif.

Piaget (dalam Nurhayani, 2015:345) berpendapat bahwa konflik merupakan peristiwa terjadinya ketidakseimbangan struktur kognitif mahasiswa yang mendorong terjadinya peralihan dari satu hal ke hal yang lain. Ia yakin bahwa konflik antar teman sebaya merupakan penyebab penting dari perubahan egosentris kepada penyesuaian terhadap pendapat orang lain. Inilah manfaat terjadinya konflik intelektual, dimana seseorang akan menjadi aktif dalam memproses informasi sosial. Hasil penelitian Diani dan Narsa (2017:146) menyimpulkan bahwa Perilaku whistleblowing Aparatur Pengawasan Internal Pemerintah dengan level penalaran moral rendah, dipengaruhi oleh kondisi ada atau tidaknya konflik peran, yaitu dari tidak mau mengungkapkan kesalahan yang ditemukan menjadi ragu-ragu. Dalam situasi terdapat konflik peran, individu dengan level penalaran moral rendah akan mengutamakan kepentingan pribadinya (selfinterest). Stage 2 Kohlberg (1969) yakni level pre-conventional juga menyatakan hal yang sama, yaitu individu yang memiliki level penalaran moral rendah memiliki motivasi utama untuk kepentingan pribadinya. Jefferson (1996) bahwa perbedaan pendapat akan menggugah keinginan untuk mencari, dan terus mencari kebenaran. Oleh karena itu, pembelajaran konflik intelektual dapat memotivasi atau menantang mahasiswa untuk memecahkan masalah atau menemukan informasi yang terlihat sukar namun dekat dengan mahasiswa sehingga pembelajaran lebih nyata dan bermakna.

Berdasarkan uraian di atas, maka dapat disimpulkan bahwa ada peran positif model pembelajaran konflik intelektual terhadap kecerdasan interpersonal mahasiswa prodi PIAUD FITK UIN Sumatera Utara Medan.

\section{SIMPULAN}

Berdasarkan hasil penelitian di atas, maka dapat disimpulkan bahwa Penerapan model pembelajaran konflik intelektual berdampak pada aspek kognitif mengenai permasalahan pengembangan emosional anak, afektif dan psikomotorik mahasiswa. Aspek kognitif, yaitu: mampu menyebutkan pengertian, karakteristik, penyebab, menyelesaikan masalah dan menemukan solusi. Aspek afektif, yaitu: mampu mengendalikan diri dan berbicara santun, serta mau berbagi dan mendengarkan orang lain. Aspek psikomotorik, yaitu: mampu 
memotivasi orang lain, mau mengarahkan dan mengatur orang lain. Ketiga aspek tersebut merupakan pencapaian materi perkuliahan pengembangan emosional anak usia RA.

Model pembelajaran konflik intelektual terbukti memberikan peran positif terhadap kecerdasan interpersonal mahasiswa prodi PIAUD FITK UIN Sumatera Utara Medan. Hal tersebut berdasarkan rerata skor postes mahasiswa yang menerapkan model pembelajaran konflik intelektual $(90,93)$ jauh lebih tinggi dari sebelum menerapkan model $(51,17)$. Perbandingan rerata skor tersebut mendukung hasil uji hipotesis yakni nilai sig. 0,001 lebih kecil 0,05 sehingga terbukti bahwa konflik intelektual berperan terhadap kecerdasan interpersonal.

\section{DAFTAR PUSTAKA}

Creswell, J. Riset Pendidikan. Yogyakarta: Pustaka Pelajar, 2015.

Diani, Rury Citra., Narsa, I Made. Level Penalaran Moral Dan Konflik Peran: Studi Eksperimen Bagi Model Perilaku Whistleblowing Aparat Pengawasan Internal Pemerintah. Jurnal Tata Kelola \& Akuntabilitas Keuangan Negara, Vol. 3 (2) Juli 2017, h. 146

Gunkel, Marjana., Schlaegel, Christopher., Taras, Vas. Cultural values, emotional intelligence, and conflict handling styles" a global study, Journal of World Business, Vol. 51, 2016, pp: 568

Jefferson, Thomas. Academic Controversy: enriching college instruction through intellectual conflict. ASHE-ERIC Higher Education Reports, Vol. 25 (3) 1996, pp: 111-123

Kohlberg, Lowrence. Stage and sequence: The cognitive development approach to socialization. Dalam D. A. Goslin (Ed.), Handbook of socialization theory (347480). Chicago, IL: Rand McNally, 1969.

Krahe, B. The Social Psychology of Aggression: Social Psychology a Modular Course. United Kingdom:Psychology Press Ltd: Taylor and Francis group, 2001.

Kristiyanto, Almunawar. Strategi Penanganan Anak Temper TantrumMelalui Terapi Permainan Puzzle Di TK DesaJatingarang (Studi Kasus di Kelurahan Jatingarang Tahun 2013), Jurnal Fakultas Keguruan dan Ilmu Pendidikan UM Surakarta, Tahun 2013, h. 9.

Lincoln, Y.S., Guba, E.G. Naturalistic Inquiry. Beverly Hills London. New Delhi: Sage Publication, 1985.

Maria, Fitricilia., Umboh, Adriana., Kaunang, David. Hubungan Enuresis Dengan Infeksi Saluran Kemih PadaAnak Usia 6-8 Tahun di SD Negeri Malalayang. Jurnal eBiomedik (eBM), Vol. 1 (1), Maret 2013, h. 464-465.

Miles, MB., Huberman, A.M. Qualitative Data Analysis, 2nd ed. USA: Sage Publication, 1994.

Mosik, Maulana P. Usaha Mengurangi Terjadinya Miskonsepsi Fisika Melalui Pembelajaran dengan Pendekatan Konflik Kognitif, Jurnal Pendidikan Fisika Indonesia, Vol. 6, Juli 2010, h. 98

Nurhayani. Kontroversi Akademik: Pengayaan Pembelajaran di Perguruan Tinggi dengan Konflik Kognitif. Jurnal Tarbiyah. Vol. 22 (2) Juli 2015. 
Oviyanti, Fitri. Urgensi Kecerdasan Interpersonal Bagi Guru, Jurnal Tadrib, Vol. III (1) Juni 2017, h. 75

Prasetyo, Maulana. Pengaruh Pendekatan Konflik Kognitif dalam Pembelajaran Fisika untuk Mengurangi Terjadinya Miskonsepsi Fisika. Skripsi. Semarang: UNNES, 2009.

Safaria, Tengku. Interpersonal Intelligence. Yogyakarta: Amara Books, 2005.

Santoso. Soegeng. Pendidikan Anak Usia Dini. Jakarta: Citra Pendidikan, 2002.

Setiowati, Erni Agustina. Studi Kasus: Dampak Psikososial Enuresis Pada Remaja Putri, Jurnal Proyeksi, Vol. 7 (1) 2012, h. 107

Setyowati., Mosik, Subali. Mplementasi Pendekatan Konflik Kognitif Dalam Pembelajaran Fisika Untuk Menumbuhkan Kemampuan Berpikir Kritis Siswa SMP Kelas VIII, Jurnal Pendidikan Fisika Indonesia, Vol. 7, Juli 2011, h. 89

Sugiyono. Metode Penelitian Kuantitatif, Kualitatif, dan R\&D. Bandung: Alfabeta, 2013.

Sulistyorini, Lantin. Pengaruh Permainan Kooperatif Terhadap Reaksi Temper Tantrum PadaAnak Usia Pra Sekolah (3-6 Tahun), Nurseline Journal, Vol. 1 (2) Nopember 2016, h. 234.

Susantyo, Badrun. Memahami Perilaku Agresif: Sebuah Tinjauan Konseptual. Jurnal Informasi, Vol. 16 (03), Tahun 2011. h. 189.

Suyadi dan Maulidya Ulfah. (2016). Konsep Dasar PAUD. (Bandung: PT. Remaja Rosdakarya Bandung).

Tentama, Fatwa. Perilaku Anak Agresif: Asesmen dan Intervensinya. Jurnal KesMas, Vol. 6 (2) Juni 2012. h. 169.

Usman, Husaini. Pengantar Statistika. Jakarta: Bumi Aksara, 2009.

Wulansari, Mutiara. Perilaku Tantrum Anak Usia 5-6 Tahun di TK Marditama Timbulharjo Sewon Bantul. Skripsi. Yogyakarta: FIP Universitas Negeri Yogyakarta, 2015.

Yoshi, Restu., Yusri. Studi Tentang Perilaku Agresif Siswa di Sekolah. Jurnal Ilmiah Konseling, Vol. 2 (1) Januari 2013. h. 249.

Yu, Chun-Sheng,. Sardessai, Ron M., Lu, June. Relationship of emotional intelligence with conflict management styles: an empirical study in China, Int. J. Management and Enterprise Development, Vol. 3 (2), 2006, pp: 34-36

Yusuf, Ayu Safitri. Hubungan Toilet Training dengan Kontrol Enuresis (mengompol) Pada Anak Usia 3-6 Tahun di Desa Tarasu Kecamatan Kajuara Kabupaten Bone. Skripsi. Makassar: UIN Alauddin Makassar, 2012. 